\title{
THE HISTORY OF LITERATURE AND ITS ETHNOPOETICS: REALIZATION OF A LARGE SCALE PROJECT
}

История литературы Урала. Конец XIV - XVIII в. / глав. ред: В. В. Блажес, Е. К. Созина. - М. : Языки славянской культуры, 2012. 608 с. : ил.

A History of Literature in the Urals: From The End of the $14^{\text {th }}$ Century To the $18^{\text {th }}$ / ed. by Valentin Blazhes and Elena Sozina. - M. : Yazyki slavianskoi kultury, 2012. - 608 p.: ill.

The review analyzes, in the context of ethnopoetics, A History of Ural Literature. Late $14^{\text {th }}-18^{\text {th }}$ Centuries, co-authored by a number of scholars. The author points out the innovative character of the publication which covers newly discovered literary sources, summarizes the information about the collections of manuscripts and private libraries, and explores the factors of the emergence and development of a regional literature. The book under consideration provides an interesting concept of the multinational literature of the Urals, and outlines a system of cultural centres in which literature and book-learning played a significant role. Among the considerable achievements of the research in question is the reporting of the artistic biographies of writers, some relying on new materials. This is the first research of the kind establishing correlations between the history of the exploration of the Russian East and the unique nature of the literary works of the region.

Keywords: Ural literature; culture of the Urals; exploration of the Urals; cultural centre; ethnopoetics.

The first volume of the planned three of the History of Literature in the Urals is out of press. This major project of the Urals-Siberian humanitarian community has its own uneasy history. The tribulations of the project are described in the Preface to the First Volume, and proper acknowledgements are made to all who started the work - along with Professor Ivan Dergachev, an early enthusiast of the systematic cataloguing and studying of Urals literature, other researchers who were interested in reclaiming and contextualising the 'peripheral' (i. e. not written in Moscow or St. Petersburg) regional literatures. 
In the preface, written by Academic V. V. Alexeyev, the actuality and necessity of a thorough research of the literature in the Urals is clearly stated; as of the "major region of Russia that from the end of the $14^{\text {th }}$ century has had its place and status in history, geography, and culture; as well as serving as the crossroads of many cultures and peoples during the previous millennium."

The main selection criteria and research methodology are outlined in the Editorial preface by Elena Sozina and K. V. Anisimov. Considering both the rich history of, and contemporary research tendencies in regional studies, the following research principles can be identified: 1) historicity in the analysis of the literature of the region and its literature process; 2) interaction of the national literatures in the region bearing in mind the cultural autonomy of every nation and its multiple identities that find their reflection in various texts; 3 ) a systematic approach towards the development of literature in the region in the context of Russian or, in some cases, world literatures; 4) maximum objectivity in research, attempting full and detailed description of the most prominent representatives, important for: a) the region and its culture, b) separate entities in the bigger region (Udmurt, Bashkir, or Komi literature; literature of the Tyumen region, etc.), and c) "for the expression of the wider national tendencies in the literature of a certain historic period, mainly all-Russian tendencies" (p. 23).

The following criteria are set for the selection of the individual writers in the research: 1) the cultural (often also political, social, religious, etc.) significance for the region and /or Russia in total;2) the expression of the idée fixe of the given region in the works of the author, as well as the presence of general strategies that put the Urals literature into a wider all-Russian context; 3) the level of personal artistic talent of the author and the importance of her/his aesthetics; 4) the reflection of the Urals theme in the creative work of the author and her/his interest in the history or present day of the region (p. 23).

The Editors specifically limit the research to authors whose life is connected to the Urals in some way: firstly, those who were born in the Urals (if and only if their writing has touched upon the problematics of the region); secondly, those authors whose life and writing has been connected to the region for shorter periods of time; and thirdly, those authors who have only passed through the Urals, or have not passed but have left a 'trace' in the literature of the region. Thus, the literature map of the Urals is not identical to its geographical and historic maps (p. 23).

The Introduction to the first volume (written by Valentin Blazhes, Larisa Soboleva, and Elena Sozina) identifies the uniqueness of the research in which for the first time the literature of the Urals is represented as a polyethnic system. In this work, purposeful characteristics are given to Bashkir, Russian, Udmurt, and Komi (both oral and written) traditions, because "To represent multi-national Urals literature historically as a cultural phenomenon with its thematic and aesthetic autonomy, is primarily to determine the uniqueness of the medieval literature, its organic connection to folklore, to 
outline the role of Christianity and Islam in the formation of the literature, as well as the meaning of Slavic writing tradition as connected to Komi and Udmurt literatures" (p. 31).

The First Volume of the "History of the Urals Literature" was initially conceived as an academic-level project, architectonically complex and scientifically clear. The research owes its complexity to the enormous time and space spans involved. However, the scientific professionalism and the editors' attention to detail have produced a complex eight-section construction of the research that encompasses four centuries and four national literatures within one region and one literary process.

The first part of the first volume, "Orthodox Traditions in Cultural and Historic Development of the Perm Lands" (P. F. Limerov, and Larisa Soboleva), consists of two chapters. The first contains systemic research of the spiritual and cultural role of Stephan Permsky (St. Stephan of Perm) whose life is found in both oral and written traditions ("The Life of Stephan Permsky" by Epiphany Premudry). The second chapter describes the written sources and literature works of Perm Vychegodskaya. The analysis shows that, while being conceptually whole, the image of Stephan Permsky has its variations in written and oral traditions. So for example, in the work of Epiphany Premudry (the end of the $14^{\text {th }} \mathrm{c}$.), "The Perm lands are represented not as alien and hostile but as acquired by the spiritual efforts of the Russian Saints, as part of the common Orthodox church and the Russian princes' politics.

The image of Stephan appears to be connected not only to hagiographic tradition but also to historic myth about the acquisition of the Urals. "The Life of Stephan" promoted further advancement towards the East, and created a successful model of interaction between the capital and the periphery. It also propagated sympathy towards the native peoples, considering them as Orthodoxy followers" (p. 51).

In the oral legends of the Komi it is not the state-and-religious role of Stephan that is emphasized; he rather appears as a hero, he is perceived not as or not solely as a saint but also as a cultural hero: "heroic and mystic traits in his image clearly prevail over his sanctity" (p. 58). Moreover, bearing in mind that "the texts of the legends and tales about Christianising are created within the context of Christianity and have adequate description of the events," then, clearly, "there was another, pagan (chud') point of view of this process, and the circle of native texts that existed and has been circulated until the Christianising was finished" (p. 58).

In any case, as the Perm Vychegodskaia written sources and literature tradition conclusively show, "Stephan began his mission as religious teacher with the creation of the Perm alphabet, thinking that a specific literary and written ethnic culture of Perm might be formed on the basis of this alphabet. This indeed happened, and the advancement of the new Christian religion promoted the ethnic and confessional consolidation of the Perm tribes into a single Komi nation. The development of the literary culture, in its turn, was the beginning of the written history of the Komi” (p. 59). 
The second part of the volume, "Medieval Bashkir Literature" (by A. H. Vildanov, M. H. Idelbaev, M. H. Nadergulov, R. Z. Shakurov, Z. Ya. Sharipova; translated into Russian by A. H. Hakimova), is dedicated to the history of the appearance $\left(9^{\text {th }}-15^{\text {th }} \mathrm{cc}\right.$. $)$ and the development $\left(16^{\text {th }}\right.$ $18^{\text {th }} \mathrm{cc}$.) of Bashkir literature.

The researchers divide medieval Bashkir literature into four major periods; 1 ) the ancient sources of the Bashkir literature, pan-Turkic texts; 2) the Volga Bulgarian period; 3) the Kypchak period; 4) Bashkir literature of the $16^{\text {th }}-18^{\text {th }}$ centuries, i.e. the first centuries of the Bashkirs' inclusion into Russia. The authors analyze the social, cultural, religious and confessional, language and artistic characteristics of the given texts. Common characteristics surface during the presentational cataloguing of the main texts of the period studied. The texts include runic artefacts, "The Dictionary of Turkic Languages" by Mahmud of Kashgar, "Blessed Knowledge" by Jusuf Balasagunski, "The Book of my Grandfather Korkut" and "The Tale of Jusuf” by Kul Gali, "Hosrov and Shirin" by Kutba, "The Book of Love" by Khorezmi, "Dzhumdzhuma Sultan" by Katib, and "Gulistan Bit-Turki" by Saifi Sarai.

The editors pay special attention to the Sufi literature that penetrated the Urals and the Volga Region via Central Asia. The Sufi literature "found favorable socio-historic ground in Bashkortostan and, gradually developing, became a distinct religious literature trend in the following centuries" (p. 94). Analyzing the Bashkir literature of the $16^{\text {th }}-18^{\text {th }}$ centuries, the researchers combine genre-oriented analysis (shezhere, tavarih, seseny, publicistic genres, hikayat, and sayahat-name) along with a focus on the author's individuality (Salavat Julaev, Mavlya Kului, Tajetdin Yalsygul Al-Bashkordi, and Gabdrahim Usman).

The common theme of this part of the volume is the idea that "the departure of some Turkic literatures from the zone-based or region-based systems and their development into national literatures happened during the $15^{\text {th }}$ and the $16^{\text {th }}$ centuries. In the Urals and the Volga regions, Tatar literature begins its existence as the national system in the $15^{\text {th }}$ century, during the Kazan Khanate epoch. Bashkir literature emerged as a national literature in the $16^{\text {th }}$ century after the inclusion of Bashkortostan into Russia. However, up until the middle of the $19^{\text {th }}$ century both literatures retained the features of the unified regional system. Thus, the regional and the national literatures coexist within one system, and create various forms of genetic and typological unity." According to the well-argued opinion of the researchers, "the Bashkir literature of the $13^{\text {th }}-18^{\text {th }}$ century, while passing through several developmental periods, saw a long evolutionary process from pan-Turkic towards national, and from medieval abstractness towards the new, realistic literature of the European kind, thus entering the $19^{\text {th }}$ century with traditional features as well as certain renovations" (p. 117).

In the third part of the volume, "Russian Hand Written Book Tradition in the Urals of the $16^{\text {th }}$ and $17^{\text {th }}$ centuries" (Valentin Blazhes, Olga Zhurav- 
el, Petr Mangilev, Natalia Mudrova, Elena Romodanovskaya, and Larisa Soboleva), it is chronologically logical that the discussion passes onto Russian literature of the Urals, and specifically the role of the Russian-language tradition (both folklore and literature) in the process of the cultural acquisition of the territory.

This part of the volume starts with the seemingly striking but inherently precise idea that "before the Urals folklore appeared, there had been folklore about the Urals" (p. 118). This section highlights the chronology of the appropriation of the Urals and the variations in its appearance and the image that were caused by the shift in the author's viewpoint and pragmatics. The author, be it a chronicle writer, a commentator, a traveler, or a storyteller, thus appeared as the person of their own historical epoch or state. Thus, in the manuscript article from 1096 "the Other," in the field of which the Urals and its peoples are attributed, is understood as "hostile." The Ugra travelogue by Sigizmund Gerberstein (1549) that is a translation of the Russian travelogue, attributed to the Novgorod traders of the $14^{\text {th }}-15^{\text {th }}$ centuries, and the Perm travelogue found and published by A. I. Pliguzov, show that foreigners are characterized strictly within the dichotomy of 'familiar' vs 'alien,' as in folk tales or stories (p. 127).

After the review of the accounts of travelers and observers, the volume gives a picture of the 'Ural text' creation in folklore and literature. The peculiarity of the Urals landscape has received "its reflection in folklore, namely, in a number of prose tale cycles" (p.128), and has also been manifested through the reference to landscape objects, and the creation of toponyms that, "along with the folk tales, have seemingly animated the territory of the Southern Urals, including it in the circle of the national acquisitions" (p. 129).

In this part the researchers discuss Ural-specific folklore genres, marked by the zoomorphic and anthropomorphic images of the 'owners' of natural treasures. The cognitive complexity of the mountainous treasures, as well as their mystic unknowability, becomes clear. Cultural appropriation of the territory is one of the powerful ways of turning it into 'little motherland' with the homestead, the family, and the household." However, the 'Ural Russia' opposition has stayed up until the beginning of the $20^{\text {th }}$ century, when it was usual to hear in the Urals: "This song is Russian," "I've served as a soldier in Russia," and "We've been brought from Russia as a whole village" (p. 133).

The second powerful movement of the cultural appropriation of the Urals territory was Christian colonisation. Christian church opuses that penetrated the Urals region, kept their 'Grace' status. All believers - the priests and the migrants, including the old-believers, - had piety in their attitude towards the church books that were hand-written or printed in Old Church Slavonic. The books were considered worth of veneration because they supposedly had exclusive powers of influence and persuasion" (p. 134). Church opuses in Old Church Slavonic laid the foundation of the literature of the Urals region. "One of the main problems connected to this 
is cataloguing the existing book collections, researching their whereabouts, numbers, compositions, and distribution" (p. 138). The author of this part of the volume singles out three types of libraries, each with its own role in the Urals' spiritual community: (a) the monastery libraries, closely connected to "the process of christianization of the region and the establishment of the administrative structure of the Russian Orthodox Church in the region"; (b) the Stroganov libraries that provided for the economic, spiritual, and educational success of Stroganov's progress in the Urals and Kama regions. A direct proof of this process is the creation of the "Stater" collection by the priest of Solykamsk Nativity Church who had finished his work in Orel, invited by Grigory Stroganov, one of the most successful 'merchants-conquerors' of this great family. (c) The third unique type of the libraries of the region is represented by the village library that belonged to the Stroganov peasants of Sludka and Ilyinskoye. It was meticulously collected by several generations of one peasant and merchant extended family. It can be concluded that "in the middle of the eighteenth century in Sludka and later in Ilyinskoye, there existed a peculiar 'reading circle' of book collectors. The peasant book lovers collected the texts and passed them between each other, as well as thoroughly copied them, because many of the texts of interest existed exclusively in manuscript form. The interesting texts were collected during longer travels. The circle of their interests was exceedingly wide, ranging from the Lives of the Saints, the Bible and bible-related books and prayers to sly or waggish tales and Apocrypha" (p. 177). An interesting fact arises in connection to this library: "the wide-scale opening of village libraries happened as a result of the Zemstvo movement as late as the end of the $19^{\text {th }}$ century. Thus, the Stroganov peasants' library was ahead of its time by more than a century" (p. 181).

Description of the Russian hagiographic texts of the Urals concludes the third part of the volume. Researchers observe that "anthropological factor based upon local leaders who possess certain charismatic power and serve as catalyzing agents in the process of a given society's self-identification can be located among the components of regional identity. This results in the appearance of local saints in the appropriated territory - a process that can be treated as obligatory within the context of Russian state politics. It is a necessary condition of the church's reinforcement, playing a safeguarding role in everyday Orthodoxy. Without local saints, one could not feel protected against hostile powers, especially in places where the collective memory of the pre-Christian history was strong" (p. 182). Thus, the Lives of Trifon of Viatka, Simeon of Verkhniaia Tura, Kosma of Verkhniaia Tura, the hagiographic sources about the Elder Dalmat, and the hagiography of Mother Superior Taisiya Kostromina, all appear in the Urals within the book and manuscript tradition of the $16^{\text {th }}-17^{\text {th }}$ centuries.

The fourth part of the volume, "The Literature and Educational Work of the Tobolsk Archdiocese House" (by Elena Romodanovskaya and Larisa Soboleva), is focused on the research of one of the most important 'cultural nests' of the Urals and Siberia region, along with Stroganov's. An important 
role in the organization of this 'nest' is "played by the bishops who presided over the Tobolsk Cathedra. Among them there were major writers, known not only in Siberia" (p. 215): Archbishop Cyprian, Archbishop Nektariy, Simeon, Ignatiy Rimskiy-Korsakov, a number of Ukrainian natives - Silvester Glovatsky, Dmitry (Tuptalo), Filofey Leshchinsky, and Johann Tobolsky (Maximovitch). Each of these individuals is connected to serious spiritual, culture curating, and creative practices; from original writings to the founding of schools, a seminary, a typography, and a theater. The development of the Tobolsk Archdiocese House led to the creation of the Yesipov Chronicle, one of the few 'authored chronicles' that can be "characterized primarily by the logic and the clarity of its structure". Yesipov, writing his Chronicle, presents Yermak as a weapon of God in the war with the infidels, as a "double-edged sword" (p. 226).

The Fifth Part, "Historical Tales in the Urals" (by Valentin Blazhes and Larisa Soboleva), is focused on the conceptualization in the regional texts of two important historical events: Yermak's Conquest of Siberia and the coming of the Old-Believers to the Urals. Several variations on events surrounding the acquisition of Siberia are found in the Stroganov Chronicle, the Kungur Chronicle, the "Tale of the Sibir Land," the "Tale of Yermak's Origins," and in the "History of Siberia" by Semen Remezov. The main methodology in studying these sources involves the idea that "treating a Chronicle as literature, it is important to keep in mind that the notions of the historic and artistic truths, while not contradicting each other, do not coincide. By changing historical reality consciously or involuntarily, by bending space and time in the artistic text, the author is heading towards another type of truth: the truth of penetration into the system of human values, and the replication of the logic of the human destinies in their relations with their epoch and society" (p. 232).

The arrival of the Old-Believers in the Urals is yet another factor in the history of the Urals' literary tradition. Analysis of the "Genealogies of the Chapel Sect" (Родословий часовенного согласия), "Genealogy of Nikon," historic "Genealogy of the Old-Believers of Pomorie," etc. leads to the conclusion that "the Old Believer type of writer developed thanks to the realization of the dramatic condition and through the personal opposition of the author to a monstrous and well-organized system of state prosecution. It has always been a choice for the suffering in the name of the truth as understood by the Old-Believers, the practical result strived towards, and formulated by the confessional unanimity of the members of the church. In this respect the Old-Believer's opuses incorporate elements of publicistics on a much wider scale than the traditional old Russian" (p. 263).

The sixth part of the volume is named "The Types of Literary Tradition in the Mining Urals of the $18^{\text {th }}$ Century" (by Valentin Blazhes, N. S. Korepanov, Elena Pirogova, Larisa Soboleva, and V. N. Solomeina). In the preface to this part, the researchers identify some characteristics of the spiritual and artistic state of the region in the period of its intense economic development. These include, firstly, the channelling of intellectual and creative 
energy into the life-supporting realm, ensuring a rather active, pragmatic attitude towards art, rather than a merely creative one. Secondly (as a consequence), not only the artistic texts, but also official documents come to occupy prime positions in the literature as it develops. Thirdly, it should be noted that literature of the border time did not know strict division into 'documentary' and 'artistic' - the feature that can explain the appearance of "the mature and thinking reader who possesses the knowledge of all literary genres and is capable of judging the text according to its cumulative qualities. The same feature shows an understanding of the need not only in pragmatic texts, but also in the aesthetically meaningful and artistically organised texts in the 18th century.

Therefore, the appearance of the unique collection of bylinas and songs compiled by Kirsha Danilov, Master Refiner from Nizhny Tagil plant, seems logical" (p. 292). The composition of the collection is daring and artistically charged: bylina follows erotic song, and historic song follows parody, spiritual poem "Golubina kniga soroka pyaden" follows a song about 'a blooming fool.' Study of the composition principles of the collection suggests a distinctive concept of time, that of the 'Epic person.' Analysis of the ways this person perceives and evaluates life events and the world, uncovering the specifics of his spirituality, which is often not recognized and not 'read' by the new time, shows that true bearers of the Epos, such as Kirsha Danilov, "raise to the heights of genuine assessment of a human being as a contradictory unity between the 'high' and the 'low' the ideal and the material. This type of assessment is reflected in the act of creation of the collection, for example, via the contamination of the 'heroic' and the 'comic' songs" (p. 302).

This part of the volume contains a further discussion of the role of the libraries in the region, indirectly supporting the thesis of the existence of a serious circle of readers in the Urals. Thus, the famous library of Akinfiy Demidov "suggests understanding of the bookish interests of the newly born Russian manufacturing bourgeoisie of the $18^{\text {th }}$ century. The composition and contents of the library differ from the known book collections of the first half of the $18^{\text {th }}$ century. It can be rather compared to the libraries of the secular elite of the post-Petrine era. $<\ldots .>$ It was not a grand and ostentatious library: much of Demidov's book collection was necessary to him as handbooks or educational resources; and an interest in the fiction cannot be excluded." (p. 309).

The final part of the chapter devoted to the intensive transformation of the Urals into the industrial treasure-house of Russia, quite naturally incorporates fragments analysing the scientific, epistolary and documentary heritage of the two founders of Yekaterinburg - Wilhelm de Hennin and V. N. Tatishchev.

The seventh part of the volume, "Documentary and fiction literature of the Enlightenment in the Urals" (by K. V. Anisimov, V. M. Vaniushev, T. G. Vladykina, D. V. Larkovich, E. E. Prikazchikova, A. G. Prokofieva, and V. Yu. Prokofieva), is one of the most structurally complex parts of the edi- 
tion. The necessity for various methodologies combined in one part can be explained by the heterogeneity of the Enlightenment literature in the Urals.

1. Firstly, the work analyses the transformation of the description of the Urals in travel notes of Western European and Russian travellers. In the notes of the $17^{\text {th }}$ century travellers (such as the arch-priest Avvakum, Nikolai Spafariy, Izbrant Ides, and Adam Brand) the image of the Urals arises as being 'witnessed' by a Russian exile or a foreigner. In Enlightenment texts (such as those by V. N. Tatishchev, G. I. Novitsky, V. F. Zuev, and A. N. Radishchev) the Urals are placed in an "ideological context that included and processed the mythology of the authority and the plots behind national and state self-identity" (p. 348).

By the end of the $17^{\text {th }}$ century the modern, familiar image of the Urals as a mountain ridge and a border between Europe and Asia emerges. This image is accompanied by the economic and professional characteristics of the 'borderland' as a mining and metal processing territory.

2. Further travelogue research continues with the study of widely present Ural memoir accounts ("Zapiski" by I. I. Nepluev, K. G. Derzhavin, A. I. Labzina, and "My Time" by G. S. Vinsky). An excellent example of the Urals memoirs tradition is "The Life Story of A Noble Woman" by the "Ural Mason' A. E. Labzina, "whose extraordinary character and will power made her one of the most interesting women of the $18^{\text {th }}$ century" (p. 357).

3. An essay on the literary life of the $18^{\text {th }}$ century Orenburg region serves as a preface to the study of K. G. Derzhavin's presence in the Urals. His early literary activities, address, albeit in embryonic form, the same problems that became central in the period of this "state poet's work in the Urals: the peculiarities of nature and the geographical position of the territory on the border between Europe and Asia, the Pugachev uprising, and the specificities of the nomadic life of the steppe peoples" (p. 371).

4. A detailed study of the state and creative activity of K. R. Derzhavin in the Urals, including the well-checked literary plots featured in his 'Ural pages' (his memoirs, "Chitalagayskiye odes," Felitsa image, etc.), offers interpretation of the little-known comic opera "Miners" in which "that ballet, conceived by Derzhavin, reflected the process of semiosis, when the traditional mythology of the peoples of the Urals seemingly gave way to a new mythology of imperial colonialism, and the pragmatic idea of the greatness of the Urals and its inexhaustible natural resources and economic opportunities was given original artistic expression" (p. 389). The creation of an 'industrial' opera (a term coined by V. V. Danilevsky) "once again confirms that the Urals left a significant trace in the life and creative work of Derzhavin. The 'Urals' poetry of Derzhavin gave way to the genre of the 'new ode' and significantly contributed to the author's rethinking of the geopolitical realities of $18^{\text {th }}$ century Russia. It also defined the main direction in which the state utopia developed, connected to the reign of 'Kyrgyz-Kaisak Tsarina Felicia.' In its turn, Derzhavin's first 'industrial' opera "Miners" anticipated the appearance of the manufacturing theme that was rigorously fed by the reality of mining life in the Urals" (p. 389). 
5. A historical essay on the development of Udmurt culture speculates upon the fact that for centuries a nation without written tradition fulfilled its magic, cognitive, and aesthetic potential through folklore. However, it was precisely "the system of forming folklore genres that prepared the ground for the perception of written culture by the nation. After the Udmurts were put into the orbit of all-Russian social, political and economic change, they found an opportunity to develop their culture in a new direction - graphically expressed literacy. The Eighteenth century in this sense becomes an important point of reference: the socio-economic and cultural development of the epoch paved the way for the first steps in the development of scientific views in the Udmurt language" (p. 392).

The final, eighth pat of the volume - "The literary process in the Urals of the late $18^{\text {th }}$ and early $19^{\text {th }}$ centuries" (by K. V. Anisimov, V. V. Blazhes, O. V. Zyrianov, D. V. Larkovich, V. A. Pavlov, V. D. Rak, and E. K. Sozina) provides an analysis of the literary process and the specificities of literary life, along with comprehensive portraits of the important writers, who were largely responsible for determining the nature of the literature of the period.

The literary process and literary life of the period, linked by a single centre (Tobolsk), are explored by the philological reconstruction both of editorial strategy and tactics, and of the artistic functioning of the first Ural-Siberian magazines "Irtysh, prevrashchayushchiysya v Ipokrenu" ("Irtysh turning into Hippocrene"), "Istoricheskaya biblioteka" ("Historical Library"), ed. D. V. Kornilyev, and "Biblioteka uchenaya, ekonomicheskaya, nravouchitelnaya, istoricheskaya i uveselitelnaya v polzu i udovolstviye vsyakogo zvaniya chitateley" ("Library scientific, economic, pious, historical, and entertaining for the benefit and enjoyment of all classes of readers"), for the latter D. V. Korniliev served as a publisher. This focus on publishing activities is understandable, since the publication of non-capital, provincial magazines "has had important implications in the literary life of the region itself. Replacing the folklore genres system, the paradigm of ancient Russian literature, as well as business correspondence and memoir writing, dominant during the preceding period and marked, as a rule, by social and utilitarian function, there came a new artistic and aesthetic paradigm that can be called literature in the full sense of the word (as artistic writing, characterized by an exclusively aesthetic function)" (p. 403). The favourable role of the magazines can be proven, for example, by the appearance of the unique circle of "Irtysh" magazine poets, each with their unique poetic voice. These are the publisher and poet P. Sumarokov, the poet, journalist, and playwright I. I. Bakhtin, and N. S. Smirnov, who was a bright and original poet of dramatic destiny, accompanied by the stigma of an exiled criminal to the end of life.

The overview of the Urals literature at the turn of the $18^{\text {th }}$ and the $19^{\text {th }}$ centuries is rounded up in this part by the three essays on authors P. A. Slovtsov, A. I. Popov, and I. I. Varakin.

P. A. Slovtsov was born in the Urals and as a particularly gifted student was sent from Tobolsk Theological Seminary to St. Petersburg, where he re- 
ceived further education. He was a person, whose literary, historiographical and nature-cataloguing activities "became one of the pivotal events in the cultural development of the Ural-Siberian region of the first half of the 19th century" (p. 480). Slovtsov was the author of "Letters from Siberia," "Walks Around Tobolsk" and "Historical Overview" ("Istoricheskoe obozrenie"), as well as poetic works (The Ode "Antiquity" ("Drevnost"), mis-attributed to Radishchev for a long time, "Message to Speransky," "Materia" etc). In his various creative works Slovtsov combined scientific academism and artistic vision: "The scientific and the artistic combined eclectically in him, and defined both the poetic individuality of the works of Slovtsov himself, and the perspectives of further literature development in the region" (p. 491).

The poet A. I. Popov represents a different direction in the literary process of the 18th century Urals - a satirical one. In 1778 in St. Petersburg this author published a collection of "Satirical, funny and moralizing epigrams or inscriptions, composed in Khlynov by the prefect of the Vyatka Seminary Anton Popov." The originality of the poet's epigrams lies in the fact that "the moralizing epigrams of A. I. Popov are deprived of characters with antique literary names. The poet speaks in the first person or in general terms of poverty and wealth, of fleeting time, of the inconsistency of social being and other 'eternal' issues. In these epigrams, the reader communicates not with a moralist with a pointing finger, but a secular person with a wide range of cultural baggage and a mockingly cheerful view of the world, typical of Russian nature" (p. 495).

The serf poet I. I. Varakin with his poetry book "Pustynnaya lira zabvennogo syna prirody I. V." ("The Deserted Lyre of Nature's Forgotten Son I. V."), (SPb., 1807) occupies a very special place in Urals literature - it "is an outstanding aesthetic achievement that occupies an important place not only in the literature of the region but also in all-Russian literature, even if he is not very well-known. It is a well composed book, not just a collection of poems. In its composition one sees the movement from the 'higher' genre of ode to the 'lower' genres of message and prosaic letter, as well as a shift of the artistic consciousness towards the lifestyle and feelings of a private person that acquire aesthetic significance. The latter is of course the brightest trait of the sentimentalist and pre-romantic periods in literature. Finally, in some works by Varakin there is a passage from individual creative consciousness to a specifically romantic usage, stimulated by his own biography" (p. 507).

We should hope that the above review of this voluminous publication demonstrates the whole scale of extensive socio-historical, cultural, and literary material analysed by the researchers, as well as the extensive work on systematising it and contextualising the long neglected or half-forgotten names of several cultural 'heroes.' This volume of the original research, in our view, is not a patchwork but instead a rich mosaic and highly complex work. The necessity of internal logic in each part of the first volume of "A History of Literature in the Urals" manifests itself in the mandatory scientific themes that have become the backbone for the whole publication 
and have ensured the integrity of the research. These themes include the relationship between literature and ethnicity, literature and history, literature and power, literature and religion, literature and folklore, literature and culture, the spiritual value of regional literature and its artistic potential, etc.

The unified algorithm of the research, conducted according to the planned 'lines of force,' is complemented by the variety of philological analysis (biographical, genre-related, stylistic, contextual, meta-textual, evolutionary, etc.), the method and the techniques of which are dictated by the specifics of the material. As a result, as the text unfolds, the unusual, sometimes unique features of the literature and literary life of the region emerge in a vivid picture, entirely correlating (in various forms, sometimes behind, sometimes in front) with the way in which literature developed in Russia as a whole.

The Academy of Sciences level and status of the publication is determined by the whole system of its qualities: the implementation of the most comprehensive description of the literary process and artistic phenomena within it; professional responsibility and rigour; the introduction of little-known or unknown facts into the scientific picture that involves an enormous archival research; the system of innovative approaches to interpretation necessarily correct towards the history of the research that has manifested itself in mandatory historiographical introductions, giving the history of the issue its maximum representativeness. Scientific controversy is presented correctly, it goes well 'inside the text,' thus saving the needed objectivity of tone. An example here might be the essay on medieval Bashkir literature, which raises the traditionally controversial issue of the culture and literature of the Bulgar period and the related problem of the origins of the belongings and beginnings of a whole row of literatures. Finally, while maintaining an individual research style, all pages bear the 'genre memory' of proper academic research. Special mention should be made of the fundamental explanatory, reference and bibliographic sections of the edition.

In the preface to the First volume the reviewers express the hope that "scientific austerity, preserved among Russian scientists," will enable the Urals literature of the $19^{\text {th }}$ and $20^{\text {th }}$ centuries to be studied. For there can be no doubt that "the Ural region nowadays takes a prominent place in the Russian Federation, so an adequate assessment of its literary and cultural heritage needs urgently to be addressed" (p. 10).

В контексте идей этнопоэтики анализируется исследование «Литература Урала XIV-XVIII вв.» (M., 2012), выполненное группой ученых. Подчеркивается новаторский характер коллективной монографии, в процессе создания которой были открыты новые литературные источники, собраны сведения о рукописных коллекциях и библиотеках частных лиц, выявлены факторы возникновения и развития региональной литературы. По мнению автора, вниманию читателей 
предложена интересная концепция многонациональной литературы Урала, обрисована система «культурных гнезд», в которых важное место занимала литература и книжность. Существенным достижением стало обращение к творческим судьбам создателей артефактов, выполненное с привлечением новых материалов. Это первое исследование подобного рода, где устанавливается взаимосвязь истории освоения российского пространства на востоке и неповторимость литературного творчества региона.

Ключевы е слова: литература Урала; культура Урала; освоение Урала; культурное гнездо; этнопоэтика.

Tatiana Snigireva (Снигирева Татьяна Александровна), prof. Russia, Yekaterinburg Ural Federal University tas0905@rambler.ru 